\title{
PENGARUH JUMLAH BLADE DAN VARIASI PANJANG CHORD TERHADAP PERFORMANSI TURBIN ANGIN SUMBU HORIZONTAL (TASH)
}

\author{
I Kade Wiratama, I Made Mara, L. Edsona Furqan Prina \\ Program Studi Teknik Mesin \\ Fakultas Teknik Universitas Mataram \\ Email: kwiratama@tm.ftunram.ac.id
}

\begin{abstract}
The willingness of electrical energy is one energy system has a very important role in the economic development of a country's survival. As one energy source (wind) can be converted into electrical energy with the use of a horizontal axis wind turbine. Wind Energy Conversion Systems (WECS) that we know are two wind turbines in general, ie the horizontal axis wind turbine and vertical axis wind turbine is one type of renewable energy use wind as an energy generator. The purpose of this study was to determine the effect of the number of blade and the radius chord of rotation ( $n)$, Torque $(T)$, Turbine Power $(P)$, Power Coefficient $(C P)$ and Tip Speed Ratio $(\lambda)$ generated by the horizontal axis wind turbine with form linear taper. The results show that by at the maximum radius of the chord $R 3$ the number blade 4 is at rotation = $302.700 \mathrm{rpm}$, Pturbine $=7.765$ watt, Torque $=0.245 \mathrm{Nm}, \lambda=3.168$ and $\mathrm{Cp}=0.403$ or $40.3 \%$.
\end{abstract}

Keywords: Torque, Chord, Coefficient Power and Tip Speed Ratio.

\section{A. PENDAHULUAN}

Ketersediaan energi listrik dalam sistem penyediaan energi nasional merupakan hal yang sangat penting dan juga mempunyai peran sangat besar dalam kelangsungan perkembangan ekonomi suatu negara. Terlebih lagi saat ini dimana ketersediaan cadangan energi yang berasal dari fosil yang semakin menipis maka akan memunculkan tantangan yang harus dihadapi oleh pemerintah dalam penyediaan kebutuhan energi akibat dari bertambahnya jumlah penduduk dan juga peningkatan perekonomian. Dalam Kebijakan Energi Nasional, salah satu kebijakan utama pengembangan energi nasional adalah meningkatkan diversifikasi energi melalui upaya pemanfaatan energi terbarukan seperti panas bumi, tenaga air, energi surya, energi angin dan biomassa dimana ditargetkan sebesar $17 \%$ menggunakan energi terbarukan dari total energy mix pada tahun 2025. Dengan memanfaatkan energi terbarukan maka ketergantungan penggunaan bahan bakar fosil pada sistem penyediaan energi nasional dapat dikurangi Selain itu, isu pemanasan global yang dikaitkan dengan konsumsi bahan bakar fosil menjadi salah satu alasan untuk mengurangi tingkat penggunaan bahan bakar fosil.

Mengingat kedepan peran energi terbarukan yang sangat penting dalam sistem penyediaan energi nasional, maka diperlukan kebijakan yang mendukung keberlanjutan pelaksanaannya.

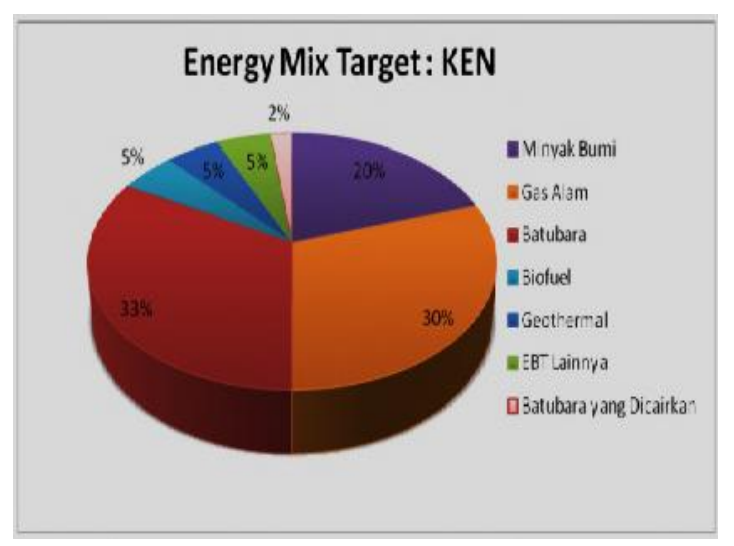

Gambar 1. Target energy mix Kebijakan Energi Nasional (KEN), [1 6].

Tabel 1. Pengelompokan potensi energi angin, pemanfaatan dan lokasi potensial.

\begin{tabular}{|c|c|c|c|c|}
\hline KELAS & $\begin{array}{l}\text { Kec. Angin } \\
\text { (mis) }\end{array}$ & $\begin{array}{c}\text { Daya Spcsifik } \\
\left(\mathrm{W}_{\text {tII }}{ }^{2}\right)\end{array}$ & $\begin{array}{l}\text { Kapasitas } \\
(\mathrm{kW})\end{array}$ & Lokasi \\
\hline Skicla Kecil & $2,5 \cdot 4,0)$ & $<75$ & sid 10 & $\begin{array}{l}\text { Jewa, NTH, } \\
\text { STT, Malukn, } \\
\text { sulawesi }\end{array}$ \\
\hline Skada Yezengah & $4,0-5,0$ & $75-150$ & $10-100$ & $\begin{array}{l}\text { VIB, III, } \\
\text { Sulsel, Sultra }\end{array}$ \\
\hline Skala Besa" & $>5,0$ & $>150$ & $>100$ & $\begin{array}{l}\text { Sulsel, VIB: } \\
\text { NTT, Pantai } \\
\text { Sclatan Jaria }\end{array}$ \\
\hline
\end{tabular}

(Sumber : [1 6])

Dari data tabel 1 menunjukkan bahwa energi angin sangat potensial untuk 
dimanfaatkan sebagai sumber penggerak kincir angin untuk menghasilkan energi listrik (SKEA). Untuk mendapatkan efek kontinuitas putaran turbin angin pada rentang kisaran tersebut maka efesiensi penangkap angin (baling-baling) haruslah dibuat seefektif mungkin. Olehkarena itu pertimbangan aerodinamik terhadap efek variasi kecepatan angin dan faktor baling- baling seperti bentuk sudu, jumlah sudu dan variasi panjang chord serta variasi luasan penangkap angin akan sangat berpengaruh terhadap out put energi yang dihasilkan.

Berdasarkan permasalahaan diatas terkait kebutuhan energi listrik dan potensi energi angin yang bisa dikembangkan maka investigasi yang dilakukan bertujukan untuk memperoleh performansi turbin angin poros horizontal yang maksimal dengan mengetahui pengaruh jumlah blade dan radius chord pada turbin angin sumbu horizontal.

\section{B. LANDASAN TEORI \\ Energi Angin}

Teori Momentum Elementer Betz

Besarnya effisiensi teoritis turbin angin $\mathrm{Cp}$ adalah 0,593, [2 5]. Dengan kata lain, rotor turbin angin akan mampu mengkonversikan energi angin menjadi daya rotor (daya berguna) tidak lebih dari $60 \%$ dari tenaga total angin. Betz adalah orang pertama yang menemukan nilai ini, untuk itu nilai ini disebut juga dengan Betz Factor.

\section{Turbin Angin}

\section{Efisiensi Turbin Angin}

Efisiensi Rotor

Daya angin maksimum yang tersedia pada turbin angin dengan luas sapuan rotor $\mathrm{A}$ adalah:

$$
P=\frac{16}{27} \frac{1}{2} \rho A^{3}
$$

maka daya yang dapat diektrak menjadi daya rotor pada turbin angin menjadi:

$$
P=C p \frac{1}{2} \rho A V^{3}
$$

\section{Daya Turbin Angin}

Daya adalah energi per satuan waktu. Daya angin berbanding lurus dengan kerapatan udara, dan kubik kecepatan angin, seperti diungkapkan dengan persamaan berikut:

$$
\begin{aligned}
& \text { Daya Angin } P=\frac{1}{2} \rho A V^{3} \\
& \text { Daya Turbin } P=T . \omega
\end{aligned}
$$

dimana :

$$
\omega=2 . \pi \cdot \frac{\mathrm{n}}{60},[3] .
$$

dimana, $\mathrm{P}=$ Daya (Watt)

$$
\begin{aligned}
\rho & =\text { Massa jenis angin }\left(\mathrm{Kg} / \mathrm{m}^{2}\right) \\
A & =\text { Luas Penampang }\left(\mathrm{m}^{2}\right) \\
V & =\text { Kecepatan Angin }(\mathrm{m} / \mathrm{s}) \\
\mathrm{T} & =\text { Torsi }(\mathrm{Nm}) \\
\omega & =\text { Kecepatan sudut }(\mathrm{rad} / \mathrm{s}) \\
\mathrm{n} & =\text { kecepatan putaran }(\mathrm{rpm})
\end{aligned}
$$

Tip speed ratio

Tip speed ratio (rasio kecepatan ujung) adalah rasio kecepatan ujung rotor terhadap kecepatan angin bebas. Untuk kecepatan angin nominal yang tertentu, tip speed ratio akan berpengaruh pada kecepatan rotor.

Tip speed ratio dihitung dengan persamaan:

dimana :

$$
\lambda=\frac{2 \cdot \pi \cdot n \cdot r}{60 \times V}
$$

$$
\begin{array}{ll}
\lambda & : \text { tip speed ratio } \\
r & : \text { jari-jari rotor }(\mathrm{m}) \\
\mathrm{n} & : \text { putaran rotor }(\mathrm{rpm}) \\
V & : \text { kecepatan angin }(\mathrm{m} / \mathrm{s})
\end{array}
$$

Konstruksi Turbin Angin

Blade

Untuk mendapatkan performan yang optimal dari sebuah kincir angin ketika dioperasikan maka perlu diperhatikan sebagai berikut:

a. Bentuk blade seperti sekrup atau memuntir, sehingga aerodinamisnya semakin baik.

b. Untuk mendapatkan energi yang lebih baik sayap-sayap dipasang langsung pada rotor.

c. Untuk blade yang ideal berjumlah 3 buah blade, karena menghasilkan pembagian gaya dan keseimbangan yang lebih baik, [4].

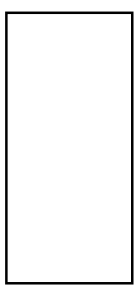

Persegi Panjang

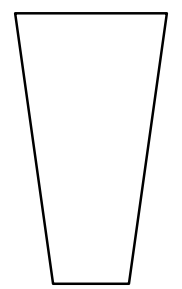

Taper linier terbalik

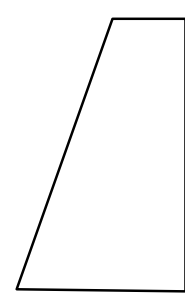

Taper linier
Gambar 2. Jenis Jenis Model Blade,[1]. 
Rope brake gambar :

Sistem rope brake di tunjukkan pada

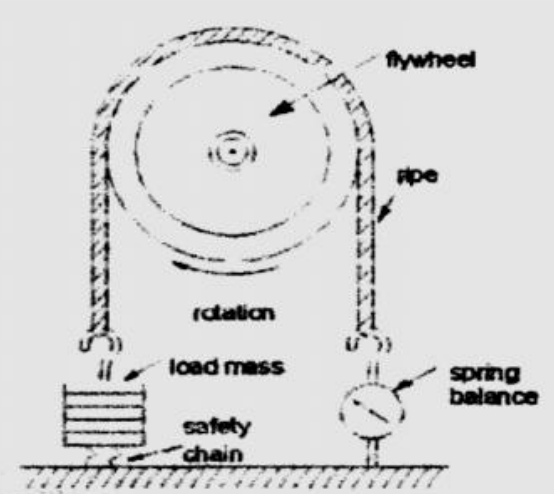

Gambar 3. Sistem Rope Brake, [5].

Sistem ini biasanya digunakan untuk mesin dengan kecepatan yang relatif lambat untuk mencari torsi.

$$
\begin{aligned}
\mathrm{T} & =\text { Gaya Tangensial } \times \text { Radius } \\
& =9,81(\mathrm{M}) \frac{D f+d r}{2}
\end{aligned}
$$

Ket : $\quad \mathrm{Df}=$ Diameter flywheel $(\mathrm{m})$

$$
\begin{aligned}
& \mathrm{dr}=\text { Diameter rope }(\mathrm{m}) \\
& \mathrm{M}=\text { Beban Pengereman }(\mathrm{Kg})
\end{aligned}
$$

\section{METODELOGI PENELITIAN Metode Penelitian}

Penelitian ini dilakukan dengan menggunakan metode penelitian eksperimental (experimental research) yaitu melakukan pengamatan untuk mencari data dalam suatu proses melalui eksperimen sehingga dapat mengetahui pengaruh jumlah blade dan variasi panjang chord terhadap unjuk kerja turbin angin sumbu horizontal.

\section{Variable-Variable Penelitian}

Variable terikat: Daya Turbin ( $\mathrm{P}$ ), Putaran ( $\mathrm{n}$ ), Torsi ( $\mathrm{T}$ ), Tip speed ratio ( TSR), Coefficient Power (CP)

Variabel bebas: Variasi panjang chord sendiri yang dibuat menggunakan pipa pvc sebesar $\mathrm{R} 1=45 \mathrm{~mm}, \mathrm{R} 2=60 \mathrm{~mm}$ dan $\mathrm{R} 3=$ $75 \mathrm{~mm}$ : Jumlah blade yang digunakan yaitu 2, 3, 4 dan 5 blade.

\section{Prosedur Penelitian}

Tahap Drawing

Untuk tahap drawing ini menggunakan bantuan software, yaitu AutoCad. Pada tahap drawing juga menentukan bahan-bahan yang akan digunakan dalam pembuatan turbin angin tersebut.

Tahap Pembuatan Berikut model turbin angin yang digunakan dalam penelitian

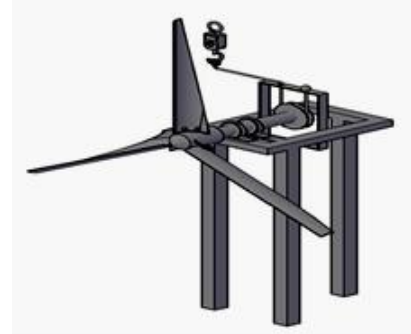

Gambar 4. Gambar Turbin Angin

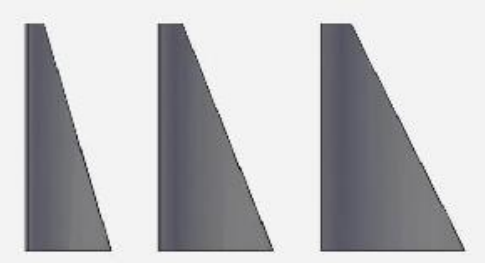

Gambar 5. Bentuk Blade

Tahap Pengujian

Pengujian model dilakukan di laboratorium dimana untuk mendapatkan kecepatan angin digunakan bantuan kipas angin dengan mengatur kecepatan angin. Setelah kecepatan nominal angin ditentukan, maka pengujian dengan cara menggunakan angin buatan yang dihasilkan oleh sebuah kipas atau fan. Kecepatan angin yang dihasilkan fan diukur dengan menggunakan anemometer sesuai dengan kecepatan angin yang diinginkan dengan cara memindahkan jarak antara fan dengan objek penelitian yaitu prototype turbin angin. Variasi panjang chord $\mathrm{R} 1$, R2, dan R3 dan jumlah blade 2, 3, 4, dan 5 blade.

\section{Metode Pengumpulan Data}

Pada pengujian ini data-data yang akan diamati adalah parameter kecepatan angin yang diukur dengan menggunakan Anemometer, putaran poros turbin yang diukur dengan menggunakan Tachometer dan gaya pengereman untuk menghitung torsi turbin angin menggunakan rope brake.

\section{Pengolahan Data.}

Data yang di yang diperoleh nantinya akan digunakan untuk menghitung Torsi ( $T$ ), Coefficien Power ( $\mathrm{Cp}$ ), Tip Speed Ratio $(\lambda)$, dan Daya Listrik $(P)$ yang dimiliki oleh turbin 
kemudian diolah didalam rumus dan di tampilkan dalam bentuk grafik.

Tahap Analisa Data

Pada tahap ini dilakukan uji statistik terhadap data-data yang didapatkan pada tahap pengujian. Selain itu juga dianalisa dengan membandingkan grafik manakah yang lebih baik, sehingga dihasilkan suatu data yang sesuai dengan tujuan awal penelitian.

\section{Pelaksanaan Penelitian}

Tahap persiapan pada tahap ini dilakukan persiapan sebelum melakukan penelitian yaitu pemasangan alat, melakukan inspeksi pada setiap objek penelitian, mengoperasikan peralatan pendukung dan melihat kondisi lingkungan apakah kondisi pengujian dapat dilakukan untuk mendapatkan hasil hasil yang optimal

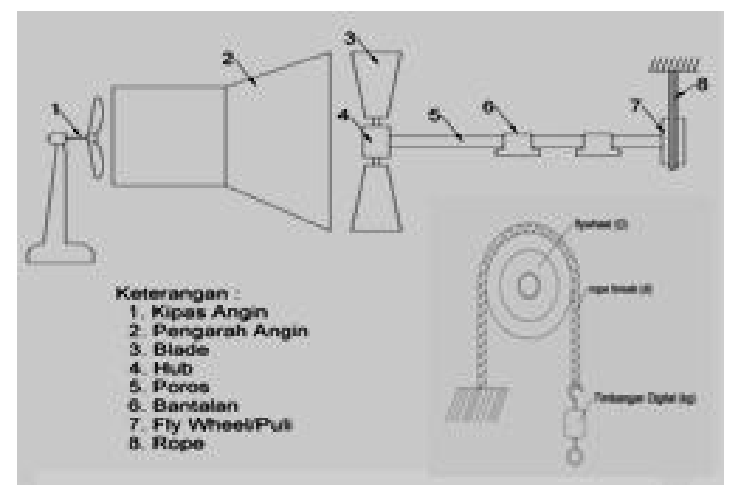

Gambar 6. Set-Up Alat Uji dan Benda Uji

Tahap pengujian dan pengambilan data sehingga setelah keempat point tahap persiapan di atas terpenuhi dan pengambilan data dapat dilakukan.

\section{HASIL DAN PEMBAHASAN}

\section{Hasil}

Tabel 2. Hasil Pengambilan Data Untuk Putaran (n).

\begin{tabular}{|c|c|c|c|}
\hline \multirow{2}{*}{$\begin{array}{c}\text { Jumlah } \\
\text { Blade }\end{array}$} & \multicolumn{3}{|c|}{ Jumlah Putaran Turbin (RPM) } \\
\cline { 2 - 4 } & $\mathrm{R} 1$ & $\mathrm{R} 2$ & $\mathrm{R} 3$ \\
\hline 2 & 182,500 & 187,400 & 195,700 \\
2 & 180,900 & 185,900 & 195,600 \\
2 & 181,800 & 186,700 & 195,800 \\
\hline 3 & 229,200 & 258,300 & 287,200 \\
3 & 228,900 & 258,300 & 287,800 \\
3 & 228,900 & 258,200 & 287,400 \\
\hline 4 & 242,700 & 270,800 & 302,600 \\
4 & 243,000 & 270,600 & 303,500 \\
4 & 242,900 & 270,300 & 302,000 \\
\hline 5 & 239,800 & 262,600 & 294,300 \\
5 & 239,700 & 262,800 & 294,500 \\
5 & 239,700 & 262,300 & 294,600 \\
\hline
\end{tabular}

Tabel 3. Hasil Pengambilan Data Untuk Beban Pengereman.

\begin{tabular}{|c|c|c|c|}
\hline \multirow{2}{*}{$\begin{array}{c}\text { Jumlah } \\
\text { Blade }\end{array}$} & \multicolumn{3}{|c|}{ Beban Pengereman $(\mathrm{Kg})$} \\
\hline & $\mathrm{R} 1$ & $\mathrm{R} 2$ & R3 \\
\hline 2 & 0.105 & 0.120 & 0.150 \\
\hline 2 & 0.105 & 0.125 & 0.155 \\
\hline 2 & 0.105 & 0.125 & 0.150 \\
\hline 3 & 0.155 & 0.295 & 0.570 \\
\hline 3 & 0.147 & 0.295 & 0.590 \\
\hline 3 & 0.145 & 0.290 & 0.580 \\
\hline 4 & 0.307 & 0.540 & 0.844 \\
\hline 4 & 0.304 & 0.548 & 0.843 \\
\hline 4 & 0.305 & 0.545 & 0.845 \\
\hline 5 & 0.268 & 0.357 & 0.675 \\
\hline 5 & 0.266 & 0.353 & 0.677 \\
\hline 5 & 0.265 & 0.355 & 0.674 \\
\hline
\end{tabular}

\section{Pembahasan}

1. Hubungan Jumlah Blade dan Panjang Chord Terhadap Putaran (RPM).

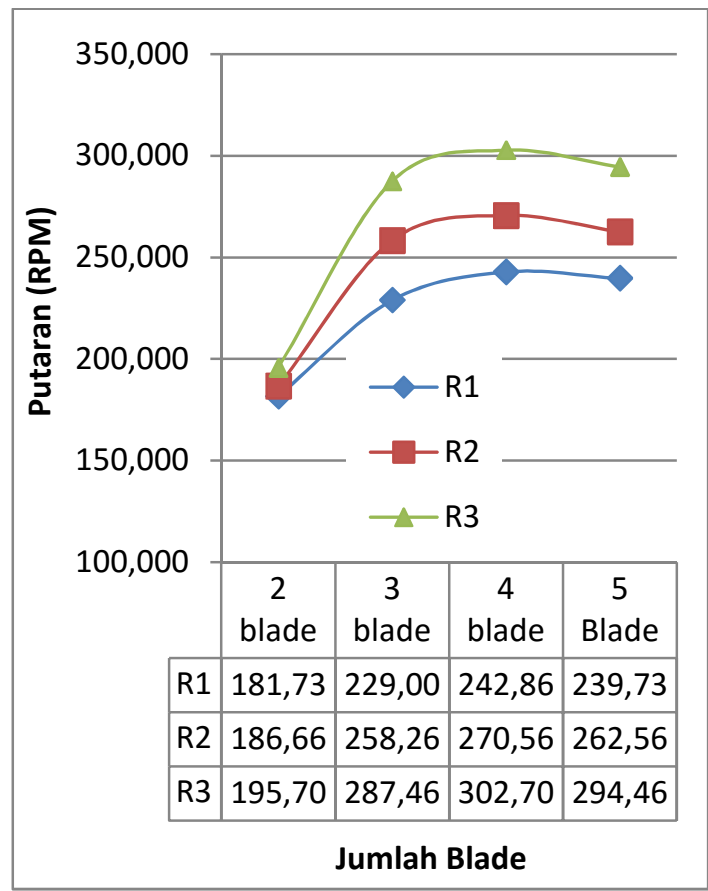

Gambar 7. Grafik hubungan jumlah blade dan panjang chord terhadap putaran.

Dari grafik hubungan jumlah blade dan panjang chord terhadap putaran menunjukkan bahwa putaran maksimal yang dihasilkan oleh turbin angin sebesar 302,700 rpm dengan besar panjang chord maksimal R3 pada jumlah blade 4, sedangkan untuk putaran minimal yang terjadi pada besar panjang chord R1 sebesar 181,733 rpm pada jumlah blade 2 . 
Tabel 4. Analisa Statistik ANOVA Untuk Jumlah Putaran (RPM) Turbin Angin.

\begin{tabular}{|l|c|c|c|c|c|}
\hline \multicolumn{6}{|c|}{ Anova Putaran (RPM) Dengan Taraf Signifikan 1 \% } \\
\hline $\begin{array}{l}\text { Source of } \\
\text { Variation }\end{array}$ & $S S$ & $d f$ & MS & $F$ & F crit \\
\hline $\begin{array}{l}\text { Jumlah } \\
\text { Blade }\end{array}$ & 41148,87 & 3 & 13716,29 & 78753,82 & 4,718051 \\
\hline $\begin{array}{l}\text { Radius } \\
\text { Chord }\end{array}$ & 13151,8 & 2 & 6575,901 & 37756,37 & 5,613591 \\
\hline $\begin{array}{l}\text { Interaction } \\
\text { Within }\end{array}$ & $\begin{array}{c}2191,311 \\
4,18\end{array}$ & 6 & 365,2185 & 2096,948 & 3,666717 \\
\hline \hline Total & 56496,16 & 35 & 0,174167 & & \\
\hline
\end{tabular}

Jika melihat data berdasarkan analisa statistik anova untuk Jumlah Putaran (RPM) maka terlihat bahwa dengan dilakukannya variasi variasi jumlah blade dan panjang chord berpengaruh sangat nyata terhadap jumlah putaran yang dihasilkan oleh turbin dengan taraf signifikan $1 \%$ hal ini terbukti dari nilai $F$ ( $F$ hitung) yang lebih besar dari $F$ crit ( $F$ tabel), Hal yang sama juga ditunjukkan oleh hubungan interaksi yang terjadi dari kedua variasi yang dilakukan.

2. Hubungan Jumlah Blade dan Panjang Chord Terhadap Torsi (T).

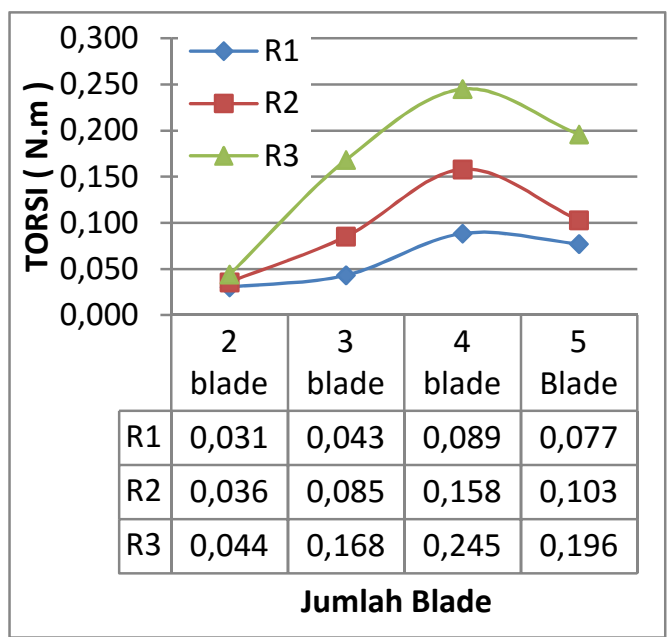

Gambar 8. Grafik hubungan jumlah blade dan panjang chord terhadap Torsi.

Dari grafik hubungan jumlah blade dan panjang chord terhadap Torsi meunjukkan bahwa torsi maksimum yang dihasilkan pada jumlah blade 4 dan panjang chord maksimal R3 sebesar Torsi 0,245 N.m, sedangkan daya minimum terjadi pada panjang chord terkecil R1 dan jumlah blade 2 sebesar Torsi 0,031 N.m.
Tabel 5. Analisa Statistik ANOVA Untuk Nilai Torsi Yang Dihasilkan.

\begin{tabular}{|c|c|c|c|c|c|}
\hline \multicolumn{7}{|c|}{ Anova Torsi Dengan Taraf Signifikan 1\% } \\
\hline $\begin{array}{c}\text { Source of } \\
\text { Variation }\end{array}$ & $S S$ & $d f$ & $M S$ & $F$ & F crit \\
\hline $\begin{array}{c}\text { Jumlah } \\
\text { Blade }\end{array}$ & 21,18515 & 3 & 7,061715 & 28054,62 & 4,718051 \\
\hline $\begin{array}{c}\text { Radius } \\
\text { Chord }\end{array}$ & 21,99895 & 2 & 10,99947 & 43698,47 & 5,613591 \\
\hline Interaction & 7,406862 & 6 & 1,234477 & 4904,303 & 3,666717 \\
\hline Within & 0,006041 & 24 & 0,000252 & & \\
\hline \hline Total & 50,597 & 35 & & & \\
\hline
\end{tabular}

Berdasarkan Tabel 5 yaitu analisa statistik anova di atas maka dengan dilakukannya variasi jumlah blade dan variasi panjang chord berpengaruh sangat nyata terhadap nilai torsi yang dihasilkan oleh turbin dengan taraf signifikan 1\% hal in terbukti dari nilai $F$ ( $F$ hitung) yang lebih besar dari $F$ crit ( $F$ tabel). Hal yang sama juga ditunjukkan oleh hubungan interaksi dari keduanya dimana dari data tetap terlihat bahwa $F$ ( $F$ hitung) lebih besar dari $F$ ( $F$ crit).

3. Hubungan Jumlah Blade dan Panjang Chord Terhadap Daya Turbin.

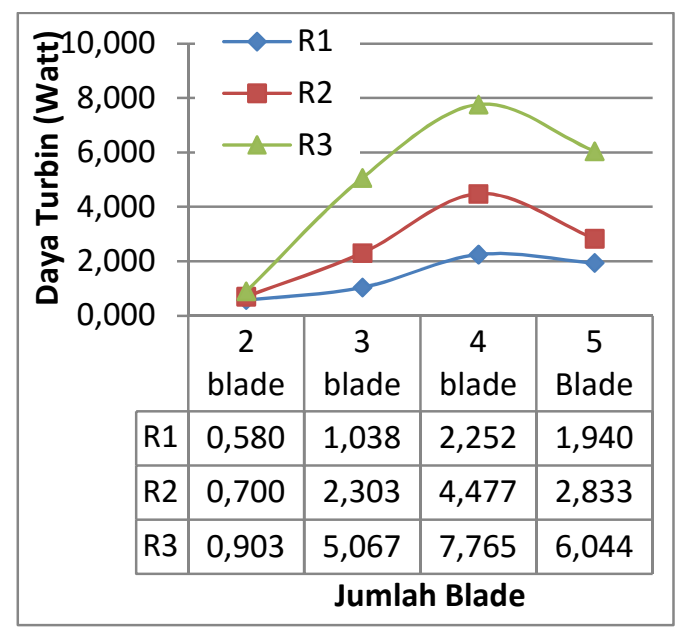

Gambar 9. Grafik hubungan jumlah blade dan panjang chord terhadap daya turbin.

Dari Gambar 9 menunjukan bahwa daya maksimum yang dihasilkan pada jumlah blade 4 dan panjang chord terbesar R3 sebesar $P$ turbin 7,765 watt, sedangkan daya minimum terjadi pada panjang chord terkecil $\mathrm{R} 1$ dan jumlah blade 2 sebesar $\mathrm{P}$ turbin 0,580 watt yang dihasilkan dari perkalian torsi $(T)$ dengan kecepatan sudut $(\omega)$ yang diukur secara berurutan menggunakan rope brake dan tachometer pada saat penelitian. 
Tabel 6. Analisa Statistik ANOVA untuk Daya Turbin (Watt).

\begin{tabular}{|c|c|c|c|c|c|}
\hline \multicolumn{6}{|c|}{ ANOVA Daya Turbin dengan taraf signifikan 1\% } \\
\hline $\begin{array}{c}\text { Source of } \\
\text { Variation }\end{array}$ & SS & $d f$ & $M S$ & $F$ & $F$ crit \\
\hline $\begin{array}{c}\text { Jumlah } \\
\text { Blade }\end{array}$ & 80,3512 & 3 & 26,78373 & 23350,69 & 4,718051 \\
\hline $\begin{array}{c}\text { Radius } \\
\text { Chord }\end{array}$ & 76,04565 & 2 & 38,02283 & 33149,19 & 5,613591 \\
\hline Interaction & 23,4433 & 6 & 3,907216 & 3406,403 & 3,666717 \\
\hline Within & 0,027529 & 24 & 0,001147 & & \\
\hline \hline Total & 179,8677 & 35 & & & \\
\hline
\end{tabular}

Dari Tabel 6 menunjukkan bahwa dengan dilakukannya variasi jumlah blade dan panjang chord berpengaruh sangat nyata terhadap daya turbin yang dihasilkan dengan taraf signifikan $1 \%$ hal ini terbukti dari nilai $F$ ( $F$ hitung) yang lebih besar dari $F$ crit ( $F$ tabel). Hal yang sama juga ditunjukkan oleh hubungan interaksi yang terjadi dari kedua variasi yang dilakukan.

4. Hubungan Jumlah Blade dan Panjang Chord Terhadap CP.

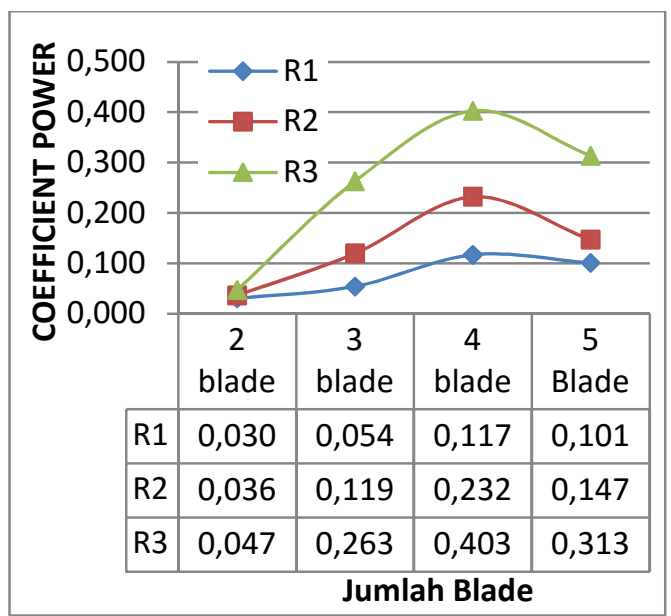

Gambar 10. Grafik hubungan jumlah blade dan panjang chord terhadap CP.

Nilai $\mathrm{Cp}$ ini diperoleh dengan cara membandingkan nilai daya mekanis real dengan nilai daya teoritis, Dari perhitungan $\mathrm{Cp}$ diketahui bahwa nilai $\mathrm{Cp}$ terbaik diperoleh pada panjang chord maksimal R3 dan jumlah blade 4 dengan nilai CP 0,403 atau $40,3 \%$, sedangkan untuk nilai terkecil $\mathrm{CP}$ diperoleh pada panjang chord $\mathrm{R} 1$ dan jumlah blade 2 yaitu dengan nilai CP 0,030 atau $3,0 \%$.
Tabel 7. Analisa Statistik ANOVA untuk Coeffisient Power (RPM) Turbin Angin.

\begin{tabular}{|c|c|c|c|c|c|}
\hline \multicolumn{6}{|c|}{ ANOVA Coefficient power (CP) dengan tarif signifikan 1\%, } \\
\hline $\begin{array}{c}\text { Source of } \\
\text { Variation }\end{array}$ & $S S$ & $d f$ & $M S$ & $F$ & F crit \\
\hline $\begin{array}{c}\text { Jumlah } \\
\text { Blade }\end{array}$ & 0,215209 & 3 & 0,071736 & 21600,1 & 4,718051 \\
\hline $\begin{array}{c}\text { Radius } \\
\text { Chord }\end{array}$ & 0,204917 & 2 & 0,102458 & 30850,62 & 5,613591 \\
\hline Interaction & 0,06339 & 6 & 0,010565 & 3181,155 & 3,666717 \\
\hline Within & $7,97 \mathrm{E}-05$ & 24 & $3,32 \mathrm{E}-06$ & & \\
\hline \hline Total & 0,483595 & 35 & & & \\
\hline
\end{tabular}

Jika melihat data berdasarkan Tabel 7 maka dengan dilakukannya variasi jumlah blade dan variasi radius chord berpengaruh sangat nyata terhadap coefficient power yang dihasilkan oleh turbin dengan taraf signifikan $1 \%$ hal ini terbukti dari nilai $F(F$ hitung) yang lebih besar dari $F$ crit ( $F$ tabel). Hal yang sama juga ditunjukkan oleh hubungan interaksi yang terjadi dari kedua variasi yang dilakukan.

5. Hubungan Jumlah Blade dan Panjang Chord Terhadap TSR

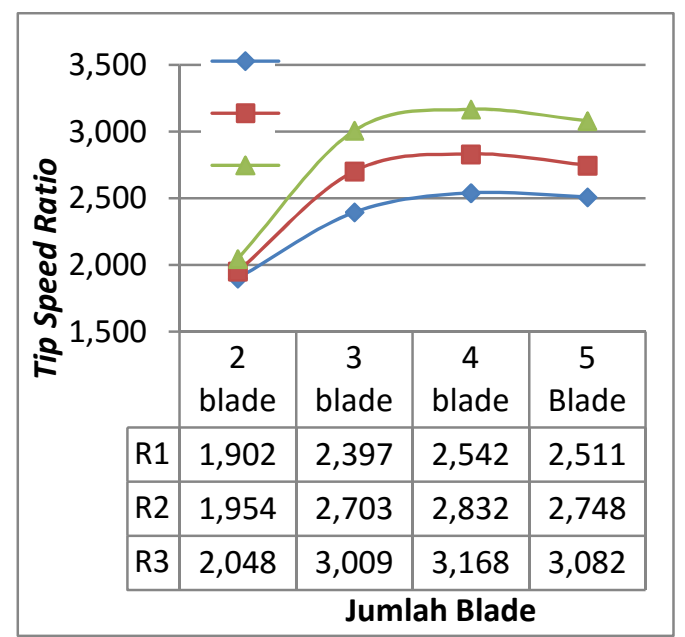

Gambar 11. Grafik hubungan jumlah blade dan panjang chord terhadap TSR.

Dari Gambar 11 menunjukkan bahwa nilai $\lambda$ maksimal pada jumlah blade 4 dan panjang chord maksimal R3 lebih besar dibandingkan jumlah blade yang lain, hal ini karena faktor penentu dari $\lambda$ seperti kecepatan angin dan putaran, sehingga dengan semakin meningkatnya putaran turbin maka $\lambda$ yang dihasilkan akan meningkat.

Untuk semua pengujian blade, nilai $\lambda$ maksimal pada panjang chord maksimal R3 terjadi pada jumlah blade 4 yaitu sebesar $\lambda \max =3,168$, sedangkan untuk nilai 
terendah pada panjang chord R1 dihasilkan pada jumlah blade 2 yaitu sebesar $\lambda$ min $=1,902$.

Tabel 8. Analisa Statistik ANOVA Untuk Nilai Tip Speed Ratio Yang Dihasilkan.

\begin{tabular}{|c|c|c|c|c|c|}
\hline \multicolumn{5}{|c|}{ Anova Tip speed ratio Dengan Taraf Signifikan $1 \%$} \\
\hline $\begin{array}{c}\text { Source of } \\
\text { Variation }\end{array}$ & SS & $d f$ & $M S$ & $F$ & $F$ crit \\
\hline $\begin{array}{c}\text { Jumlah } \\
\text { Blade }\end{array}$ & 4,505229 & 3 & 1,501743 & 78730,635 & 4,718051 \\
\hline $\begin{array}{c}\text { Radius } \\
\text { Chord }\end{array}$ & 1,44171 & 2 & 0,720855 & 37791,664 & 5,613591 \\
\hline Interaction & 0,239285 & 6 & 0,039881 & 2090,7975 & 3,666717 \\
\hline Within & 0,000458 & 24 & $1,91 \mathrm{E}-05$ & & \\
\hline \hline Total & 6,186682 & 35 & & & \\
\hline
\end{tabular}

Dari Tabel 8 menunjukkan bahwa dengan dilakukannya variasi jumlah blade dan variasi panjang chord berpengaruh sangat nyata terhadap nilai tip speed ratio yang dihasilkan oleh turbin dengan taraf signifikan $1 \%$ hal ini terbukti dari nilai $F(F$ hitung) yang lebih besar dari $F$ crit ( $F$ tabel). Hal yang sama juga ditunjukkan oleh hubungan interaksi dari keduanya dimana dari data tetap terlihat bahwa $F$ ( $F$ hitung) lebih besar dari $F$ ( $F$ crit).

\section{E. KESIMPULAN DAN SARAN Kesimpulan}

Dari rangkaian investigasi dilakukan maka dapat ditarik beberapa kesimpulan sebagai berikut :

1. Putaran yang dihasilkan pada turbin angin sumbu horizontal dengan jumlah blade 4 lebih baik bila dibandingkan dengan jumlah blade 2, 3 dan 5. Panjang chord R3 lebih baik dari R1 dan R2.

2. Unjuk kerja Turbin paling maksimum dihasilkan oleh turbin angin pada panjang chord R3 dengan jumlah blade 4 yaitu putaran $=302,700 \mathrm{rpm}, \mathrm{P}_{\text {turbin }}=7,765$ Watt, Torsi $=0,245$ N.m, $\lambda=3,168$ dan Cp $=0,403$ atau $40,3 \%$.

3. Unjuk kerja turbin yang dihasilkan pada panjang chord R3 dengan jumlah blade 4 lebih baik bila dibandingkan jumlah blade yang lainnya.

4. Variasi Jumlah Blade dan Panjang chord berpengaruh signifikan terhadap Putaran, Torsi, Daya Turbin, Coefficient Power dan Tip Speed Ratio dilihat dari hasil analisa statistik ANOVA.

5. Turbin angin hasil rancangan ini dapat dijadikan referensi untuk pengembangan dan penelitian Sistem Konversi Energi Angin ( SKEA) selanjutnya.

\section{Saran}

Dalam penelitian ini turbin angin yang digunakan adalah turbin angin sumbu horizontal dengan blade berbentuk taper linier, perlu dilakukan beberapa modifikasi dari bentuk blade yang berbentuk lengkung dengan memvariasikan arah lengkungan ditambah dengan bentuk rata. Selain itu perlu penelitian lebih terhadap sudut serang yang optimum digunakan untuk bentuk dasar blade turbin angin apakah dapat mempengaruhi unjuk kerja yang dihasilkan oleh turbin angin sumbu horizontal.

\section{DAFTAR PUSTAKA}

[1] Tim CASINDO Nusa Tenggara Barat, 2011, Rencana Aksi Energi Terbarukan Provinsi Nusa Tenggara Barat, Laporan $D$-25. Mataram.

[2] Hau, E., 2006, Wind Turbines Fundamentals, Technologies,Application, Economics. Edisi Kedua. Germany. Springer.

[3] Djuhana., 2013, Metode Pengukuran Momen dan Daya, Jakarta : Pusat Pengembangan Bahan Ajar, UMB.

[4] Alamsyah, H., 2007, Pemanfaatan Turbin Angin Dua Sudu Sebagai Penggerak Mula Alternator Pada Pembangkit Listrik Tenaga Angin, Tugas Akhir, Universitas Negeri Semarang.

[5] Anonim 2, 2013, Torque, The Rope Brake 